\title{
Serum levels of copper, zinc and disease severity scores in sickle cell disease patients in Benin City, Nigeria
}

\author{
Mathias A Emokpae, Emmanuel B Fatimehin, Progress A Obazelu
}

\begin{abstract}
Department of Medical Laboratory Science, School of Basic Medical Sciences, College of Medical Sciences, University of Benin, Benin City, Nigeria.
\end{abstract}

Emails: Progress.obazelu@uniben.edu; emmiesphere@gmail.com

\begin{abstract}
Background: Micronutrient deficiency is recognized in sickle cell anaemia (SCA) but it is not known for certain whether changes in zinc, copper and copper-to-zinc ratio are associated with Sickle cell disease severity scores.

Objective: To compare serum levels of copper, zinc and copper-to-zinc ratio in SCA subjects with control group and correlate the variables with objective disease severity scores.

Methods: Serum copper and zinc were determined in 100 SCA patients and 50 controls using kits supplied by Centronic, Germany. Unpaired Students't-test was used to compare the variables between SCA patients in steady clinical state, vaso-occlusive crisis and controls, while Spearman correlation coefficient was used to associate the parameters with disease severity scores.

Results: Serum copper level was higher $(\mathrm{P}=0.008)$ in SCA patients than controls, while serum zinc level was lower $(\mathrm{P}<0.001)$ in SCA patients than controls. The copper/zinc ratio was higher $(\mathrm{P}<0.001)$ in SCA patients than controls. Significantly higher $(\mathrm{P}<0.001)$ copper and lower $(\mathrm{P}<0.001)$ zinc levels were observed in patients in vaso-occlusive crisis than in steady clinical state. Zinc correlated inversely $(\mathrm{r}=-0.2743 ; \mathrm{P}=0.006)$ while copper-to-zinc ratio correlated positively with disease severity scores.

Conclusion: Copper-to-zinc ratio may be an indicator of disease severity in SCA patients.

Keywords: Copper/zinc ratio, disease severity score, sickle cell anaemia.

DOI: https://dx.doi.org/10.4314/ahs.v19i3.56

Cite as: Emokpae MA, Fatimehin EB, Obazelu PA. Serum levels of copper, zinc and disease severity scores in sickle cell disease patients in Benin City, Nigeria. Afri Health Sci. 2019;19(3): 2798-2805. bttps:// dx.doi.org/10.4314/abs.v19i3.56
\end{abstract}

\section{Introduction}

Sickle cell disease (SCD) is an inherited disorder of major health challenge in sub-Saharan African including Nigeria. The condition is characterized by haemolytic anaemia and periodic painful crisis as a result of occlusion of small blood vessels due to spontaneous intravascular red blood cells polymerization at reduced oxygen tension ${ }^{1}$. The associated complications of SCD include growth
Corresponding author:
MA Emokpae,
Department of Medical Laboratory Science,
School of Basic Medical Sciences,
College of Medical Sciences,
University of Benin, Benin City, Nigeria
Email: mathias.emokpae@uniben.edu

retardation, impaired immune functions, acute chest syndrome, abdominal pain ${ }^{3}$, proteinuria ${ }^{4}$, increased oxidative stress and damage to cell membranes ${ }^{5}$. Some authors have documented scoring indices with which to assess disease severity in subjects with Sickle cell anaemia (SCA), using parameters such as anaemia score, white blood cell count score, complication score and blood transfusion score $\mathrm{s}^{6,7}$. Zinc is involved in several cellular metabolism, plays a role in immune function ${ }^{8,9}$, wound healing ${ }^{10}$, protein DNA synthesis as well as cell division ${ }^{11}$. It also plays a role in the maintenance of proper sense of taste and smell ${ }^{12,13}$, supports growth and development ${ }^{14-17}$. Zinc possesses anti-oxidant ${ }^{15}$ and anti-microbia ${ }^{18}$ properties and confers protection against accelerated ageing ${ }^{15}$.

Copper is also an important micro-nutrient and is essential for maintaining the strength of the skin, blood vessel, epithelial and connective tissues. It plays a role in the

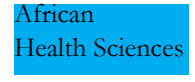

(C) 2019 Emokpae et al. Licensee African Health Sciences. This is an Open Access article distributed under the terms of the Creative commons Attribution License (https://creativecommons.org/licenses/BY/4.0), which permits unrestricted use, distribution, and reproduction in any medium, provided the original work is properly cited. 
production of haemoglobin, myelin, melanin and proper functioning of thyroid gland. It also acts as both antioxidant and pro-oxidant ${ }^{19-21}$. Both copper and zinc form part of the superoxide dismutase (Cu-Zn-SOD) antioxidant system. The enzyme plays important role of scavenging free radicals generated during the course of normal body metabolism. It was also observed that calcium binding to red blood cells membrane may be responsible for the formation of irreversible sickled cells and zinc acts as anti-sickling ion because it is able to antagonize calcium binding to red blood cell membrane ${ }^{22}$. Sickle cell disease is a disorder that is characterized by increased oxidative stress and lipid peroxidation. Low anti-oxidant status may predisposes the subjects to vaso-occlusive crisis $^{23-25}$. We previously reported lower levels of serum copper and zinc in SCA patients which were associated with higher demand of antioxidants for tissue repair as a result of proteinuria ${ }^{26}$, inflammation ${ }^{5}$. Okocha et $\mathrm{al}^{27}$ had evaluated the levels of some micronutrients and disease severity score in patients with SCD in Eastern Nigeria. Other authors also reported on the relationship between painful crisis and serum zinc level in subjects with SCA ${ }^{28}$. The authors observed that it is not known for certain if zinc deficiency in SCA is associated with Sickle cell disease severity score $^{28}$. An insignificant relationship between serum zinc level and disease severity was reported from University College Hospital, Ibadan, Nigeria ${ }^{29}$. The authors reported that even though the level of zinc in the patients was significantly lower than controls, no correlation with disease severity score was observed. The limitation of the previous studies was small samples which makes it difficult to draw concrete inference. This study was designed to compare serum levels of copper, zinc and copper-to-zinc ratio in SCA subjects with control group and to correlate the variables with disease severity score.

\section{Patients and methods}

\section{Selection of study participants}

This is a case control study of SCA patients conducted at Specialist Hospital, Benin City, Nigeria.

One hundred (100) confirmed SCA patients (74 in steady clinical state and 26 with painful crisis) were consecutively recruited while 50 age and sex matched individuals with normal haemoglobin (HbAA) were used as controls. In this study, SCA patients on steady clinical state were defined as subjects who were apparently well without evidence of recent infection, bone pain or other illnesses for at least 4 weeks and have not had blood transfusion within the last 3 months while painful crisis referred to subjects who had pains at the time of enrolment or within 48 hours before enrolment in any of the limbs ${ }^{30}$. The study participants were aged 4-20 years, 53 males and 47 females while the control group was aged 4-21 years made up of 25 males and 25 females. Severity Scoring Protocol was determined using the combination of anaemia, complications, white blood cell count and transfusion scores to generate an objective score of disease severity as follows ${ }^{31}$ :

\section{Anaemia score:}

$\mathrm{Hb} \geq 10 \mathrm{~g} / \mathrm{dl} \rightarrow 0$

$\mathrm{Hb} \geq 8 \mathrm{~g} / \mathrm{d}<10 \mathrm{~g} / \mathrm{dl} \rightarrow 1$

$\mathrm{Hb} \geq 6<8 \mathrm{~g} / \mathrm{dl} \rightarrow 2$

$\mathrm{Hb} \geq 4<6 \mathrm{~g} / \mathrm{dl} \rightarrow 3$

$\mathrm{Hb}<4 \mathrm{~g} / \mathrm{dl} \rightarrow 4$

\section{Complications score:}

Each complication was scored 1 except

-Nephropathy $\rightarrow 2$

-Stroke $\rightarrow 2$

White Cell Count score:

Count $<9 \times 103 \rightarrow 0$

Count $\geq 9<11 \times 103 \rightarrow 1$

Count $\geq 11<15 \times 103 \rightarrow 2$

Count $\geq 15 \times 103 \rightarrow 3$

\section{Transfusion score:}

Life Transfusion Rate $=$ Total Number of pints of Blood /Age

Transfusion rate was approximated to the nearest whole number.

Then the mean score of a combination of various scores represents the severity score.

Disease severity was scored as;

- Mild $(<3)$

- Moderate $(>3 \leq 5)$

- Severe $(>5)$

The minimum and maximum disease severity scores were 2 and 6 .

Inclusion criteria: The SCA subjects who were not on any zinc and copper containing medications, had not been transfused with blood or blood products within the last 3 months, none-had any symptom or signs of infec- 
tions such as fever, acute respiratory infection and diarrhea were included. The control subjects had no evidence of chronic diseases including protein energy malnutrition. The haemoglobin phenotype of all subjects was determined by haemoglobin electrophoresis using cellulose acetate paper and Tris buffer.

Exclusion criteria: Subjects excluded were those on zinc containing medications or transfused with blood or blood products in the previous 3 months before recruitment in to the study.

Ethical consideration: The study protocol was reviewed and approved by the ethics committee of the Edo state Ministry of Health with code HM.1208/II/160; dated $27^{\text {th }}$ March 2017) and all participants gave informed consent before blood specimen was collected.

\section{Specimen collection and analytical methods:}

Five millilitres $(\mathrm{mL})$ of venous blood was obtained aseptically and $2 \mathrm{~mL}$ dispensed into EDTA containing tube for full blood count while $3 \mathrm{~mL}$ was dispensed into a zinc and copper free plain container which was previously washed after soaking in 10\% nitric acid for 24 hours and rinsed three times with deionized water. The blood was allowed to clot at room temperature and centrifuged at 3000rpm for 5 minutes. The serum was separated into another cop- per/zinc free tube. The serum was stored at -200C (for a maximum of one month) until analyzed. Serum copper, zinc were assayed by colorimetric method using kits supplied by Centronic, Germany while copper/zinc ratio was calculated by dividing the value of copper with zinc value. Commercially available control sera were included in the assay to ensure accuracy of analyses.

Statistical analysis: The results obtained are presented as mean \pm standard error of the mean (SEM) and were analyzed using a statistical software package (SPSS version 20, IBM, IL, USA). Students't-test was used to compare the levels of copper, zinc and copper/zinc ratio between SCD patients in steady clinical state, vaso-occlusive crisis and controls. The measured parameters were correlated with disease severity scores using Spearman's correlation coefficient. A $\mathrm{p} \leq 0.05$ was considered as significant.

\section{Results}

Table 1 shows the comparison of measured variables between sickle cell disease patients (Hb SS) and controls ( $\mathrm{Hb} \mathrm{AA})$. Serum copper level was significantly higher $(\mathrm{P}=0.008)$ in sickle cell disease patients than controls, while serum zinc levels was significantly lower $(\mathrm{P}<0.001)$ in sickle cell disease patients than controls. Similarly copper/zinc ratio was significantly higher $(\mathrm{P}<0.001)$ in sickle cell disease patients than controls.

Table 1: Comparison of measured variables between sickle cell disease patients (Hb SS) and control subjects with normal haemoglobin (Hb AA) (Mean \pm SEM)

\begin{tabular}{llll}
\hline Measured variables & $\begin{array}{l}\text { Sickle cell anaemia } \\
\text { (HbSS) } n=100\end{array}$ & $\begin{array}{l}\text { Control subjects } \\
(\text { HbA A) } n=50\end{array}$ & P-value \\
\hline $\begin{array}{l}\text { Number of males } \\
\text { Number of females }\end{array}$ & 53 & 25 & \\
Age (Years) & 47 & 25 & $\mathrm{NS}$ \\
Serum copper $(\mu \mathrm{g} / \mathrm{dL})$ & $18.60 \pm 0.5$ & $19.00 \pm 0.6$ & 0.008 \\
Serum zinc $(\mu \mathrm{g} / \mathrm{dL})$ & $40.50 \pm 1.78$ & $102.60 \pm 1.58$ & 0.001 \\
Copper/zinc ratio & $3.35 \pm 0.16$ & $54.60 \pm 1.23$ & 0.001 \\
\hline
\end{tabular}


Table 2 shows the comparison of measured variables between sickle cell disease patients in clinical steady state (HbSS) and controls (HbAA). Serum copper level was insignificantly higher $(\mathrm{P}=0.621)$ in sickle cell disease patients in clinical steady state than controls, while serum zinc level was significantly lower $(\mathrm{P}=0.002)$ in sickle cell disease patients in clinical steady state than controls. Similarly copper/zinc ratio was significantly higher $(\mathrm{P}<0.001)$ in sickle cell disease patients in clinical steady state than controls.

Table 2: Comparison of measured variables between sickle cell disease patients ( $\mathrm{HbSS}$ ) in steady clinical state and control subjects with normal haemoglobin (HbAA) (Mean \pm SEM).

\begin{tabular}{llll}
\hline Parameters & $\begin{array}{l}\text { Sickle cell disease subjects } \\
\text { in steady clinical state } \\
(\mathbf{n = 7 4 )}\end{array}$ & $\begin{array}{l}\text { Control subjects } \\
(\mathbf{n = 5 0 )}\end{array}$ & P-value \\
\hline Serum copper $(\mu \mathrm{g} / \mathrm{dL})$ & $105.80 \pm 2.46$ & $102.60 \pm 1.585$ & 0.621 \\
\hline Serum zinc $(\mu \mathrm{g} / \mathrm{dL})$ & $46.26 \pm 1.986$ & $54.60 \pm 1.237$ & 0.002 \\
\hline Copper/Zinc ratio & $2.57 \pm 0.1069$ & $1.94 \pm 0.0516$ & 0.001 \\
\hline
\end{tabular}

Table 3 shows the comparison of measured variables between sickle cell disease patients in clinical steady state (HbSS) and vaso-occlusive crisis. Serum copper level was significantly lower $(\mathrm{P}<0.001)$ in sickle cell disease patients in clinical steady state than vaso-occlusive crisis, while serum zinc levels was significantly higher $(\mathrm{P}<0.001)$ in sickle cell disease patients in clinical steady state than vaso-occlusive crisis. Similarly copper/zinc ratio was significantly lower $(\mathrm{P}<0.001)$ in sickle cell disease patients in clinical steady state than vaso-occlusive crisis.

Table 3: Comparison of measured variables between sickle cell disease patients in steady clinical state and vaso-occlusive crisis (Mean \pm SEM)

\begin{tabular}{llll}
\hline Measured Parameters & $\begin{array}{l}\text { Sickle cell disease } \\
\text { patients in } \\
\text { steady clinical } \\
\text { state }(\mathbf{n}=\mathbf{7 4})\end{array}$ & $\begin{array}{l}\text { Sickle cell disease } \\
\text { patients in painful } \\
\text { crisis }(\boldsymbol{n}=\mathbf{2 6})\end{array}$ & P-value \\
\hline Serum copper $(\mu \mathrm{g} / \mathrm{dL})$ & $105.80 \pm 2.46$ & $131.10 \pm 4.251$ & 0.001 \\
\hline Serum zinc $(\mu \mathrm{g} / \mathrm{dL})$ & $46.26 \pm 1.986$ & $24.15 \pm 0.943$ & 0.001 \\
Copper/Zinc Ratio & $2.57 \pm 0.1069$ & $5.59 \pm 0.249$ & 0.001 \\
\hline
\end{tabular}

Serum zinc levels correlated negatively $(r=-0.274$; $\mathrm{p}=0.006)$ while copper-to-zinc ratio correlated positive$\operatorname{ly}(\mathrm{r}=0.235 ; \mathrm{p}=0.019)$ with disease severity score in SCD patients. There was however no significant correlation between serum copper levels with disease severity score.
Table 5 shows the proportion of SCD patients with mild, moderate and severe disease severity scores and the concentrations of the measured variables. The distribution indicates 20 mild, 05 moderate and 03 severe based on the scoring protocol. 
Table 4: Correlation of measured variables against disease severity scores

in sickle cell disease patients (Mean \pm SEM)

\begin{tabular}{l|ll|} 
Correlation & R-value & P-value \\
\hline Serum copper and Disease severity score & 0.062 & 0.537 \\
Serum zinc and Disease severity score & -0.274 & 0.006 \\
Copper/zinc ratio and Disease severity score & 0.235 & 0.019
\end{tabular}

Table 5: Sickle cell disease severity score categories

\begin{tabular}{l|llll|}
$\begin{array}{l}\text { Severity } \\
\text { Scores }\end{array}$ & $\begin{array}{l}\text { Number of } \\
\text { subjects }\end{array}$ & $\begin{array}{l}\text { Serum } \\
\text { Copper } \\
(\mu \mathrm{g} / \mathrm{dL}) \text { levels }\end{array}$ & $\begin{array}{l}\text { Serum } \\
\text { Zinc }(\mu \mathrm{g} / \mathrm{dL})\end{array}$ & $\begin{array}{l}\text { Copper/Zinc } \\
\text { levels }\end{array}$ \\
\hline $\begin{array}{l}\text { Mild }(<3) \\
\text { Moderate }(>3 \leq\end{array}$ & 20 & $118.01 \pm 1.20$ & $32.80 \pm 0.91$ & $3.59 \pm 0.31$ \\
$\begin{array}{l}\text { 5) } \\
\text { Severe }(>5)\end{array}$ & 05 & $130.02 \pm 0.30$ & $28.10 \pm 0.30$ & $4.62 \pm 0.23$ \\
& 03 & $135.01 \pm 0.10$ & $22.20 \pm 0.20$ & $6.00 \pm 0.05$
\end{tabular}

\section{Discussion}

Sickle cell anaemia is a disorder characterized by haemolysis, subnormal immune status, inflammation and increased susceptibility to infections and vaso-occlusive crisis. Available evidence suggests that zinc supplementation could ameliorates vaso-occlusive crisis ${ }^{32,33}$ but it is not clear whether zinc and copper levels are associated with sickle cell disease severity scores. This study was therefore conducted to correlate serum levels of zinc, copper and copper/zinc ratio with sickle cell disease severity scores in sickle cell disease patients in both steady clinical state and vaso-occlusive crisis.

Serum copper level was significantly higher $(\mathrm{P}=0.008)$ in sickle cell disease patients than controls, while serum zinc level was significantly lower $(\mathrm{P}<0.001)$ in sickle cell disease patients than control. Hence, copper/zinc ratio was significantly higher $(\mathrm{P}<0.001)$ in sickle cell disease patients than controls. This study also shows a significantly higher $(\mathrm{P}<0.001)$ copper level in patients with vaso-occlusive crisis than those in steady clinical state of sickle cell disease. The zinc level was significantly lower $(\mathrm{P}<0.001)$ leading to a significantly higher $(\mathrm{P}<0.001)$ copper/zinc ratio in vaso-occlusive crisis than steady clinical state of sickle cell disease patients. Zinc was inversely associated $(\mathrm{r}=-0.2743 ; \mathrm{P}=0.006)$ with disease severity scores, while copper-to-zinc ratio correlated positively with disease severity score.
The observed lower level of serum zinc and higher level of copper in this study is partially consistent with previous studies ${ }^{4,27,28,334,35}$. Zinc and copper are co-factors of copper/zinc superoxide dismutase (Cu/Zn-SOD) and important antioxidant enzyme that catalyze the breakdown (dismutase) of superoxide radicals into molecular oxygen or hydrogen peroxide. This helps to prevent or repair the damage caused by free radicals and also to regulate redox-sensitive signaling pathways. Deficiency of any of the two metals has been associated with reduced antioxidant activity and may potentially subject the SCD patients to increased risk of acquiring associated complications and growth retardation ${ }^{27,28}$.

Some authors who previously reported low serum zinc levels in SCD patients had attributed such low levels to increased urinary loss, adverse effects of hydroxyurea used in the management of the patients ${ }^{36,37}$ and increased demands. Okocha et $\mathrm{a}^{27}$ observed that serum copper and zinc levels were lower in both SCD patients and control subjects with normal haemoglobin. Our report however shows that the mean level of zinc in the control subjects was within normal reference range $(50-150 \mu \mathrm{g} / \mathrm{dL})$. We observed a higher level of serum copper and an insignificant correlation between serum copper and disease severity score which contradicts that reported by Okocha et $\mathrm{al}^{27}$, the authors observed that serum copper was significantly associated with disease severity score in a group of SCD patients. The observed higher level of se- 
rum copper in our study was supported by some authors who suggested that high intracellular copper may potentially induce red cell haemolysis by its ability to produce superoxide radicals in the presence of sufhydryl-group ${ }^{38}$. Intracellular haemolysis releases free haemoglobin and the free haemoglobin mop-up and depletes nitric oxide (a potent vasodilator) and plays a role in the dysregulation of arginine metabolism. This may lead to several associated complications such vaso-occlusive crisis, sickle cell nephropathy and acute chest syndrome ${ }^{39,40}$. A contradicting report from Saudi Arabia states that serum copper and zinc levels were normal and not different from those with normal haemoglobin individuals ${ }^{41}$.

The lower level of serum zinc observed in SCA subjects than control group may be attributed to several causes such as chronic haemolysis leading to loss of zinc from red blood cells, an important storage site for zinc, excessive urinary loss and increased consumption due to increased oxidative stress and redox imbalance in $\mathrm{SCA}^{25,28}$. The observed association between serum zinc and disease severity did not agree with previous studies ${ }^{4,27,28}$. The authors observed that serum zinc level in SCA patients, although significantly lower than control subjects with normal haemoglobin did not correlate with various disease severity scores. The authors stated that small sample size used in that study may be a limitation to drawing concrete inference and therefore suggested further studies that involve larger population size $e^{4,27}$. The further lowering of serum zinc in SCD patients with vaso-occlusive crisis is consistent with previous studies ${ }^{28}$. It was suggested that SCA subjects who are severely zinc deficient may be more susceptible to vaso-occlusive crisis. In addition, SCA patients with frequent vaso-occlusive crisis may not feed well thereby making nutritional deficiencies worse $\mathrm{e}^{25,28}$. The observed association between serum zinc and disease severity score is inconsistent with that reported by Garba et $\mathrm{al}^{42}$. The authors observed no significant difference in the levels of serum copper and zinc between SCA patients in steady clinical state and vaso-occlusive crisis. But in our study, the distribution of some $e^{28}$ participants spanned across mild, moderate to severe with decreasing concentration of zinc and increasing copper/zinc ratio.

Trace metals play vital role in several biological systems through their actions as activators or inhibitors, thus competing with other biomolecules for binding site, influenc- ing the permeability of membrane. It was suggested that copper-to-zinc ratio may be more valuable indicator of state of disease in affected individuals ${ }^{41}$. In SCD, serum copper level is inversely proportional to zinc and this inverse relationship precipitates the generation of reactive oxygen radicals thus exacerbating associated complications ${ }^{41}$. The low zinc and high copper levels are responsible for the higher copper-to-zinc ratio which correlated with disease severity score in SCA patients. In conclusion, low serum zinc, high copper and copper-to-zinc ratio were observed in SCA patients than control. The further lowering and increases in these variables were observed in patients with vaso-occlusive crisis. Serum zinc correlated negatively while copper-to-zinc ratio correlated positively with disease severity scores while copper shows no significant correlation with disease severity scores. This finding indicates that demand for zinc utilization in SCD patient increases with disease severity. Evaluation of copper/zinc ratio in the management of SCD patient is suggested and may serve as reference for diagnosing deficiencies and supplementation at a daily dose of zinc has been advocated. Copper-to-zinc ratio may be used as an indicator of disease severity in SCA patients.

Limitations: The inability to determine the dietary intake because of difficulty of the subjects to recall accurately and quantity of meals consumed as well as unavailability of the socioeconomic status, urinary zinc level which is a better assessment of zinc loses are limitations in this study.

\section{Acknowledgements}

We appreciate the contributions of all staff of the Central Hospital and Sickle Cell Centre, Benin City, Edo State, Nigeria. We are grateful to the Medical Laboratory Scientists for their technical support.

\section{Conflict of interest}

The author's declared no potential conflicts of interest with respect to the research, authorship, and/or publication of this article.

\section{References}

1. Asanga EE, Eseyin OA, Ekanem AN, Amaechi D. Changes in serum zinc, magnesium and copper in sickle cell patients: A case study in Jos, Nigeria. World J Pharmaceut Sci. 2016;4(5):195-199. 
2. Tagney CC, Philips G, Bell RA.Selected indices of micro-nutrient status in adult's patients with sickle cell anaemia. Ann J Hematol 1989;32:161-166.

3. Emokpae MA, Ehioghae I. Increased levels of pancreatic enzymes in sickle cell anemia and the effect of proteinuria. J Med Invest Pract 2015;10:13-15.

4. Emokpae MA, Uadia PO, Kuliya-GwarzoA . Antioxidant Enzymes and Acute phase Proteins correlate with markers of Lipid peroxide in adult Nigerian Sickle Cell Disease Patients. Iranian J Basic Med Scis 2010;13(4):177182.

5. Emokpae MA,Uadia PO, Gadzama AA. Correlation of Oxidative Stress and Inflammatory markers with the Severity of Sickle Cell Nephropathy. Annals of African Medicine 2010; 9(3):141-146.

6. Anyaegbu CC, Okpala IE, Akren'Ova YA, Salimonu LS. Peripheral blood neutrophil count and candidacidal activity correlate with the clinical severity of sickle cell anaemia (SCA). Eur J Haematol 1998;60:267-268.

7. Okocha C, Manafa P, Ozomba J, Ulasi T, Chukwuma $\mathrm{G}$, Aneke J. C-reactive protein and disease outcome in Nigerian sickle cell disease patients. Ann Med Health Sci Res. 2014; 4:701-705 PubMed .

8. Alayasha AJ. Zinc and copper status in patients with Sickle cell anaemia. Acta Haematol 1997;77:87-89.

9. Solomons NW. Mild human zinc deficiency produces an imbalance between cell-mediated and humoral immunity. Nutr Rev. 1998; 56: 27-28 PubMed .

10. Ploysangam A, Falciglia G, Brehm B. Effect of marginal zinc deficiency on human growth and development. J Trop Pediatr. 1997; 43: 192-198.

11. Prasad AS. Zinc: an overview. Nutrition 1995;11: 9399.

12. Heyneman CA. Zinc deficiency and taste disorders. Ann Pharmacother 1996;30: 186-187.

13. Prasad AS, Beck FW, Grabowski SM, Kaplan J, Mathog RH. Zinc deficiency: changes in cytokine production and T-cell subpopulations in patients with head and neck cancer and in noncancer subjects. Proc Assoc Am Physicians 1997;109: 68-77.

14. Simmer K, Thompson RP. Zinc in the fetus and newborn. Acta Paediatr Scand Suppl 1985;319: 158-163.

15. Fabris N, Mocchegiani E. Zinc, human diseases and aging. Aging 1995;7:77-93.

16. Maret W, Sandstead HH. Zinc requirements and the risks and benefits of zinc supplementation. $J$ Trace Elem Med Biol 2006;20: 3-18.
17. Institute of Medicine, Food and Nutrition Board. Dietary Reference Intakes for Vitamin A, Vitamin K, Arsenic, Boron, Chromium, Copper, Iodine, Iron, Manganese, Molybdenum, Nickel, Silicon, Vanadium, and Zinc. Washington, DC: National Academy Press 2004.p.26

18. McCarthy TJ, Zeelie JJ, Krause DJ.The antimicrobial action of zinc ion/antioxidant combinations. Clin Pharmacol Therapeut 1992;17: 5.

19. Classen HG, Gröber U, Löw D, Schmidt J, Stracke H. Zinc deficiency: Symptoms, causes, diagnosis and therapy. Med Monatsschr Pharm 2011;34: 87-95.

20. Harris ED. Copper homeostasis: the role of cellular transporters. Nutr Rev 2001;59: 281-285.

21. Groff JL, Gropper SS, Hunt SM. Advanced Nutrition and Human Metabolism. West Publishing Company, New York 1995 p.15-17

22. Brewer GJ, Oelshlegel Jr FJ. Antisickling effects of zinc, Biochem Biophysic Res Communicat 1974;58(3): 854-861. 23. Adelekan DA, Thurnham DI, Adekile AD. Reduced antioxidant capacity in paediatric patients with homozygous sickle cell disease. Eur J Clin Nutr 1989; 43(9): 609614.

24. Chow CK. Nutritional influence on cellular antioxidant defense systems. Am J Clin Nutr 1979; 32(5):10661081.

25. Hasanato RMW. Zinc and anti-oxidant vitamin deficiency in patients with severe sickle cell anemia. Ann Saudi Med 2006;26(1): 17-21.

26. Emokpae MA, Tijani AD. The impact of proteinuria on serum levels of trace elements in sickle cell disease patients. J Med Biomed Scis 2014;3(3):16-20.

27. Okocha CE, Aneke JC, Manafa PO, Nwogba SC, Ibeh NC, Onah CE. Serum micronutrient levels and disease severity score in patients with sickle cell anaemia. Egyptian J Haematol 2016;41(3):144-147.

28. Temiye EO, Duke ES, Owolabi MA, Renner JK. Relationship between painful crisis and serum zinc levels in children with sickle cell anemia. Anemia 2011(2011):1-7.

29. Akenami FO, Aken'Ova YA, Osifo BO. Serum zinc, copper and magnesium in sickle cell disease at Ibadan, south western Nigeria. Afr J Med Med Scis 1999(28):34):137-139.

30. Ballas SK, Lieff S, Benjamin LJ, Dampier CD, Heeney MM, Hoppe C, Johnson CS, Rogers ZR, Smith-Whitley K, Wang WC, Telen MJ; Investigators, Comprehensive Sickle Cell Centers. Definitions of the phenotypic manifestations of sickle cell disease. Am J Hematol. 2010;85(1):6-13. 
31. van den Tweel X.W, van der Lee J.H, Howard J, Fijnvandraat K. Measurement of Disease Severity in Patients with Sickle Cell Disease: A Systematic Review. Blood, 2007 110:2250.

32. Prasad AS, Cossack ZT. Zinc supplementation and growth in sickle cell disease. Ann Intern Med 1984; 100(3): 367-371.

33. Gupta VL, Chaubey BS. Efficacy of zinc therapy in prevention of crisis in sickle cell anemia: a double-blind, randomized controlled clinical trial. J Assoc Physicians India 1995; 43 (7):467-469.

34. Arinola OG, Olaniyi JA, Akiibnu MO. Evaluation of antioxidant level and trace element status in Nigerian sickle cell disease patients with plasmodium parasitaemia. Pak J Nutr 2008;7:766-769.

35. Bot YS, Benjamin A, Nyango DY, Ventmack DT, Eunice CB, Etukudu NS, Obeta MU. Analysis of copper and Zinc in serum of sickle cell disease patients in Jos. Int J Med Scis 2015;3(3):207-209.

36. Idonije BO, Iribhogbe OI, Okogun GRA. Serum trace element levels in sickle cell disease patients in an Urban City in Nigeria. Nature Sci 2011; 9(3): 67 - 71.

37. Sindel LJ, Dishuck JF, Baliga BS, Mankad VN. Micronutrient deficiency and neutrophil function in sickle-cell disease. Ann N Y Acad Sci 1990;587:70-77.

38. Manzler AD, Schreiner AW. Copper-induced acute hemolytic anemia. A new complication of hemodialysis. Ann Intern Med 1970; 73:409-412.

39. Wood KC, Hsu LL, Gladwin MT. Sickle cell disease vasculopathy: a state of nitric oxide resistance. Free Radic Biol Med 2008;44:1506-1528.

40. Ghosh S, Adisa OA, Chappa P, Tan F, Jackson KA, Archer DR, Ofori-Acquah SF. Extra cellular hemin crisis triggers acute chest syndrome in sickle mice. J Clin Invest 2013; 123:4809-4820 PubMed .

41. Dangi CBS, Kaur M, Singh M. Copper and zinc Quotient in Hemoglobinopathies. Biomed Pharmacol J 2011;4(1):165-173.

42. Garba N, Ifeanyichukwu OM, Amilo GJ, Audu I. Evaluation of Trace elements in adult sickle cell anaemia patients in Zaria, north western Nigeria. J Blood Disord Transfus 2016;7:2 